\title{
NEWBORN RESUSCITATION - LONGER PERIODS OF INITIAL VENTILATION AND THE IMPACT ON MARKERS OF BRAIN INFLAMMATION IN NEWBORN PIGS
}

\author{
I. Dannevig ${ }^{1}$, A.L. Solevåg ${ }^{2}$, T. Sonerud ${ }^{2}$, O.D. Saugstad ${ }^{1}$, B. Nakstad ${ }^{2}$ \\ ${ }^{1}$ Department of Paediatric Research, Oslo University Hospital, Rikshospitalet, Oslo, ${ }^{2}$ Department of \\ Paediatrics, Akershus University Hospital, Lørenskog, Norway
}

Background: We wanted to explore if longer initial ventilation intervals than $30 \mathrm{~s}$ prior to initiation of cardiac compressions during resuscitation of newborn pigs would modulate levels of inflammatory markers in the newborn pig brain.

Material and methods: Newborn pigs were anaesthetized and mechanically ventilated. Progressive asphyxia was induced until asystole occurred. Animals received ventilation for $30 \mathrm{~s}, 60 \mathrm{~s}$ or $90 \mathrm{~s}$ before onset of chest compressions. After return of spontaneous circulation, the pigs were observed for 4 hours before cerebrospinal fluid (CSF) and samples from the brain were collected.

Results: $C S F$ : IL-6 $(\mathrm{pg} / \mathrm{ml})$ and TNF $\alpha(\mathrm{pg} / \mathrm{ml})$ were significantly lower in the $60 \mathrm{~s}$ group $(30.2 \pm 25.6$ and $34.6 \pm 27.2)$ compared to the 30 s group $(154 \pm 168.3$ and $86.2 \pm 50.7), \mathrm{p}=0.02$ and $\mathrm{p}=0.01$, respectively. There were significantly lower levels of $\mathrm{S} 100$ in the $30 \mathrm{~s}$ group $(19.1 \mathrm{ug} / \mathrm{L} \pm 20.3)$ compared to the $90 \mathrm{~s}$ group (42.1 ug/L \pm 30.7$), \mathrm{p}=0.01$.

Frontal cortex: We found no significant differences in inflammatory markers between the groups in the frontal cortex.

Hippocampus: Gene expression of MMP-2 was significantly lower in the group ventilated for $60 \mathrm{~s}$ compared to the $30 \mathrm{~s}$ group, $\mathrm{p}=0.02$.

Conclusion: We found a higher inflammatory response in pigs resuscitated from cardiac arrest to ROSC when providing ventilation for $30 \mathrm{~s}$ and $90 \mathrm{~s}$ compared to $60 \mathrm{~s}$ of initial ventilation, indicating that a slightly longer ventilation period than the recommended guidelines of $30 \mathrm{~s}$ might be beneficial. 